\title{
MATERIAŁY
}

Urszula Kicińska

Uniwersytet Pedagogiczny im. Komisji Edukacji Narodowej w Krakowie Katedra Edukacji Historycznej

Instytut Historii

\section{Ztości, która się więc pokazuje w dziateczkach nie tak winien ojciec jako matka - wpływ matki na wychowanie swych dzieci w polskich drukowanych oracjach pogrzebowych XVII wieku}

\begin{abstract}
Anger which is appearing in children, father isn't guilty only mother - influence of the mother on raising one's children in Polish printed funeral orations of the 17th century
\end{abstract}

In funeral orations, the fact of being a mother was underlined as the major merit of the dead. The number of children to whom she gave birth and whom she raised were mentioned with pride. So the motherhood constituted the main mission of the woman. Not only nursing children, but also forming their character and mind belonged to the responsibilities of women. A good mother, according to preachers, was supposed to be pious, sensible and hard-working. The Old Polish education ideal, in spite of social and material differences, had more than a class character. It concerned mainly girls, because they rarely expressed their opinion about their education and in less detail. It is possible to distinguish two types of educating women. The first one was called "conservative" and was supposed to prepare young girls for their future role of the wife, the mother and the housewife. The second was known as "progressive" as it recognized the equal status of the man and the woman and therefore she could develop intellectually. The daughters of magnates and rich gentry received their education in aristocratic manor houses or at convent schools, whereas poorer girls had to be satisfied with home upbringing. Nevertheless, irrespective of the place in which the girl received her education, she was prepared for her main practical role of the wife, the mother and the housewife.

Keywords: Motherhood, Child, Education, Funeral Orations

Mowy i kazania pogrzebowe stanowią ciekawe, choć do tej pory nieco zaniedbane źródło, z którego można czerpać wiadomości na temat staropolskich ceremoniałów rodzinnych, zwyczajów i uroczystości religijnych. Zawierają one nie tylko bogaty materiał genealogiczny i heraldyczny, ale są też znakomitym źródłem do badań nad mentalnością społeczeństwa staropolskiego ze względu na występujące w nich wyraźne pierwiastki dydaktyczne i parenetyczne, pod wpływem których kształtowały się pewne modele, 
wzorce i stereotypy osobowe w obrębie tegoż społeczeństwa ${ }^{1}$. Jednym z wielu, a zarazem zasadniczym elementem kobiecych kazań funeralnych XVII wieku było podkreślanie powagi macierzyństwa oraz kształtowanie wzorca dobrej matki, która miała istotny wpływ na wychowanie swoich dzieci, zwłaszcza córek. Oracji poświęconych samym dzieciom jest niewiele ${ }^{2}$, stąd wiadomości na temat rodzicielstwa w dawnej Polsce należy szukać przede wszystkim w kobiecych mowach pogrzebowych, które opisują cnotliwe panny, kochające matki i pobożne wdowy. One też stały się podstawą niniejszego artykułu.

W kazaniach pogrzebowych oraz w epitafiach bycie matką podkreślano jako główną zaletę zmarłej, z dumą wymieniając liczbę urodzonych i wychowanych dzieci, a sztuki piękne i literatura chętnie odwoływały się do symboliki płodności (faecunditas) i macierzyństwa, których metaforą była młoda kobieta o nagich piersiach (symbol pokarmu), $\mathrm{z}$ atrybutami $\mathrm{w}$ formie snopów zboża, kwiatów, owoców, czy też rojów pszczół ${ }^{3}$. Istotę bycia matką i posiadania potomstwa wyraził kaznodzieja Hiacynt Mijakowski w oracji poświęconej Elżbiecie Myszkowskiej (zm. przed 11 I 1644), marszałkowej koronnej. Piewca uznał bowiem, że człowiek [...] który po sobie zostawuje potomka szczęśliwy jest, ma się z czego cieszyć: bo acz sam umiera żyje w potomku4. Potomstwo to także piękny kwiat małżeństwa, o czym przeczytać możemy w mowie pogrzebowej Zofii z Dąbrowicy Lanckorońskiej (zm. 1645), kasztelanowej sądeckiej, która przez kaznodzieję Jędrzeja Cyrusa nazwana została połowicq synów, ponieważ urodziła czternaścioro dzieci (siedem

${ }^{1}$ B. Popiołek, Konterfekt prawdziwy umbra fatalnq malowany - wizerunek kobiety w staropolskich mowach pogrzebowych, „Studia Historyczne” R. 47:2004, z. 3-4, s. 313.

${ }^{2}$ Na ten temat zob. [Rajmund Piegłowski], Pokoy Y Niesmiertelnosc Iaśnie Oświeconego Włodzimierza Swatopełka Xiążęcia Czetwertyńskiego Starosty Siewińskiego. y Rodzonych Iego Teressy y Krystyny Chorążanek Wołyńskich Na iednym Katafalku w kwitnącym wieku wystawionych A Duchowna Konsolatia [...] Załosnym Rodzicom Mową pogrzebową wyrażone. Przez [...] S. Th Lektora zakonu Kaznodz: na ten czas Przeora Horodelskiego w Kościele Łuckim Dominikańskim A.D.1673. die 5. Octobris. Kraków 1675; [Mateusz Lisicki], Lodz Do Szczęsliwego Portu płynąca, Przy pogrzebinach [...] P. Jana Szołdrskiego Cześnika Ziemskiego Kaliskiego, Także Ich Mościow Panien Barbary y Jadwigi Dwu Cor [...] Szołdrskich, Kazaniem żałobnym Przez Xiędza [...] Dziekana Lwoweckiego, Plebana Kamińskiego, W Kościele Czempińskim, dnia I I. Grudnia w Roku Pańskim 1662. W drogę wieczności Wyprawiona. Poznań 1663; [Andrzej Kochanowski], Plastr Miodu Od śmierci pożarty, ale śmierci wydarty, To jest Kazanie Na pogrzebie [...] Panny Barbary Lanckorońskiey, Kasztellanki Kamienieckiey, [...] P. Stanisława z Brzezia Lanckoronskiego, Woiewody Bracławskiego, Woysk Rzeczypospol: Regimentarza, Skalskiego, Dyrymeńskiego, Stobnickiego, etc. etc. Starosty Kochaney Corki; Miane Przez [...] Karmelitę Bossego w Stobnicy w Kościele Oycow Reformatow Zakonu Franciszka świetego, Die 23. Novembris, Anno 1649. Do Druku podane za dozwoleniem Starszych. Kraków 1649.

${ }^{3}$ Por. D. Żołądź-Strzelczyk, Dzieje edukacji kobiet w Polsce przedrozbiorowej, w: Studia z dziejów edukacji kobiet na ziemiach polskich, D. Żołądź-Strzelczyk, W. Jamrożek, Poznań 2001, s. 18; B. Popiołek, Kobiecy świat $w$ czasach Augusta II. Studia nad mentalnościa kobiet z kręgów szlacheckich, Kraków 2003, s. 231.

${ }^{4}$ [Hiacynt (Jacek) Mijakowski], Zbozny Pobyt, Po śmierci Swiątobliwie Zmarłey Matrony, Jasnie Wielmożney Paniey, Margrabiney, Iey Mci Paniey Helzbiety Myszkowskiey, Marszałkowey Koronney, w Pinczowie Przy Pogrzebie ciała iey do wiadomości wszytkich podany Przez [...], Pisma S. y Theologiey Doktora, Kaznodzieię Farskiego Krakowskiego. Roku Pańskiego, M.DC.XLIV. Dnia 11. Stycznia. Z dozwoleniem Starszych, Kraków 1644, s. 23. 
córek i siedmiu synów), z którymi zwiqzała [...] piękne i dobre ich wychowanie. Jej trzech synów i dwie córki oddane zostały na służbę Bogu ${ }^{5}$.

Analiza siedemnastowiecznych kazań funeralnych dostarcza materiału pozwalającego stwierdzić jakimi słowami, bądź wyrażeniami określano matki w dawnej Polsce. Najczęściej były to epitety - „macica winna”, „mądra matka”, „Kochana Matka”, „Matrona Wielmożna”, „Persona”, „Matka żarliwa”, „najmilsza Rodzicielka Matrona”, „Matka piastownica”, „heroina”, „mądra niewiasta” oraz „przezacna Pani”. Choć określenia te nie są naładowane emocjonalnie, wskazują jednak na główne posłannictwo kobiety - jakim było rodzicielstwo i wychowywanie dzieci.

Kobieta jako matka, pełniła w rodzinie chrześcijańskiej istotną rolę, gdyż przez wychowywanie dzieci, miała wpływ na pierwsze lata ich życia. Taka postawa miała jednak swe konsekwencje, ponieważ ograniczała rozwój intelektualny kobiety, zawężając jej możliwości jedynie do macierzyństwa i administrowania domem, gdyż białogłowa porzqdna tego dokazuje, że $w$ domu jej nigdy Maż, dziatki, ubodzy i czeladka głodu nie przymiera $^{6}$, o czym wspomniał bernardyn Franciszek Kochanowski w oracji ku czci Anny Marii z Zięblic Oraczowskiej (zm. 1664).

Według lansowanego przez kaznodziejów wzorca bohaterki mów pogrzebowych nie zaznały innej miłości niż małżeńska, macierzyńska i przede wszystkim miłość Boga. Macierzyństwo było dla kobiety najważniejszą rolą życiowa, ciężko bowiem $w$ matżeństwie być ni pannq ni matka, ciężary matzeńskie ponoszac, owocu matżeństwa pociechy nie zażyć ${ }^{7}$, pisał Mikołaj Kmita w kazaniu wygłoszonym przy egzekwiach Zofii z Ostroga Lubomirskiej (zm. 1622), podczaszyny koronnej, żony Stanisława. Posiadanie dzieci nadawało sens życiu kobiety, nobilitowało ją społecznie oraz podnosiło jej pozycję w rodzinie. Stąd też duchowni chętnie kreowali w swych oracjach wizerunek idealnej matki. Ich zdaniem na takie miano zasługiwała kobieta, która kocha i rozumie swoje dzieci, daje im pobożne wychowanie oraz przesadnie ich nie rozpieszcza. Ponadto żona i matka miała być dobrą panią domu, która prowadzi liczny dwór, ale nie opływa w zbytku, posiada ogładę, zna dobre maniery i jest pobożna. Szczególnie ostatnia z wymienionych cech była dla kaznodziejów bardzo ważna, ponieważ bogobojna białogłowa dbająca o zbawie-

\footnotetext{
5 [Jędrzej (Andrzej) Cyrus], Mądra Thekuita, Na Pogrzebie [...] P. Zophiey z Dąbrowice Lanckorońskiey, Kasztellanki Sądeckiey, Małogorskiey, etc. Starosciney, Przez [...] Karmelitę Bossego: Kathedralnego Kościoła Krakowskiego Kanodzieie Ordinariusza Wystawiona. A przez X. Mikołaia Wasniowica, Kommendarza Wodzisławskiego do druku podana. Za dozwoleniem Starszych. Kraków 1645, s. 15-16; s. 18.

${ }^{6}$ [Franciszek Kochanowski], Korona Sowita Z Honoru doczesnego y Splendoru wiecznego Uwita [...] P. Annie Maryey z Zięblic Oraczowskiey Przy Akcie Pogrzebowym, Z Ambony Tarnowskiey, u Oyców Bernardynów Podana, Dnia I. Grudnia. Roku Pańskiego 1664, Przez [...] tegoż Zakonu Lectora, S. Theologiey Generalnego. Z dozwoleniem Starszych. Kaźmierz przy Krakowie 1664, s. 388.

${ }^{7}$ [Mikołaj Kmita], Kazanie Przy Exequiach [...] P. Zophiey Xiężny z Ostroga, Hrabiney na Wiśniczu Lubomirskiey, Podczaszyney Koronney, [...] P. Stanisława Hrabie na Wisniczu Lubomirskiego, Woiewody y Generała Krakowskiego, Zatorskiego, Spiskiego, Niepołomskiego, Białocerkiewskiego, etc. etc. Starosty Małzonki Swiątobliwey Pamieci. W Kościele Wiśnickim, Oycow Karmelitow Bossych Od-prawionych. 7. Maij. A.D. 1636, s. 103, [w:] tenże, Trzy Matki Urodzeniem, Pobożnoscią, Potomstwem Ozdobione, A Kazaniami Pogrzebnymi Koronie Polskiey, y Familiom ku ozdobie, Potomnym czasom do podziwienia y naśladowania wystawione y podane. Przez [...] Karmelitę Bossego, Kaznodzieie Ordynaryusza Kathedralnego Krakowskiego. Z Dozwoleniem Starszych. Kraków 1639.
} 
nie duszy i życie wieczne zasługiwała na poświęcenie jej uwagi i pochwałę. Pobożność matki winna się objawiać w postach, umartwianiu ciała, pamięci o karze Bożej i życiu wiecznym, miłosierdziu wobec bliźnich, dobroci, świętobliwości, okazywaniu pomocy i rozdawaniu jałmużny klasztorom, szpitalom, kościołom, opiece nad chorymi, uczestniczeniu w nabożnych dyskursach, pogardzie dla rzeczy doczesnych oraz czytaniu pobożnych ksiagg i modlitewników ${ }^{8}$. Takie wychowanie w domu rodzinnym we wszelakich cnotach i obyczajach otrzymała Aleksandra Radzimińska (Radzymińska) (zm. przed 20 III 1652), podkomorzyna żmudzka, którą kaznodzieja Jakub Antoni Jendrski nazwał metaforycznie - ,mądra indzienigierką”. Zmarła bowiem zbudowała sobie dwa domy. Pierwszym był „dom mądrości”, czyli przygotowywanie się przez życie na „dobrą i mądrą śmierć”, drugim zaś „dom czystości małżeńskiej”, który opierał się na religijnym wychowaniu, modlitwie, uczciwości i przystępowaniu do sakramentów świętych ${ }^{9}$. Z kolei Anna z Wierbna Ciświcka (zm. 1628), kasztelanka śremska, pochodziła z domu, w którym jej pobożni i szlachetni rodzice już za młodu wpoili córce mądrość, pokorę, trzeźwość, pobożność, zgodę sąsiedzką i małżeńską, stateczność, cierpliwość, wstydliwość, wdzięczność oraz łaskawość dla poddanych, które przydały się jej w dorosłym życiu ${ }^{10}$. Zatem bycie matką gloryfikowało kobietę i zapewniało jej szacunek otoczenia, a macierzyństwo w okresie baroku podniesione zostało do wysokiej godności. Matka zaś jako pierwsza nauczycielka swego dziecka musiała odznaczać się cnotliwością, pobożnością i rozwaga, a swą pracą powinna była dawać przykład i być wzorem do naśladowania dla swoich córek.

Staropolski ideał wychowawczy ${ }^{11}$, pomimo dużego zróżnicowania społecznego i majątkowego, w znacznym stopniu posiadał charakter ponadstanowy. Dotyczyło to głównie

${ }^{8}$ Por. B. Popiołek, Konterfekt prawdziwy ..., s. 320-322.

9 [Jakub Antoni Jendrski], Mądra Indzienigierka Dwoch Domow dla siebie Albo Kazanie pokazane Na pogrzebie [...] Paniey Alexandry Radziminskiy Ciwonowey Szawdowskiey Podkomorzyney Zmudzkiey. Przez Wielebnego Xiędza [...] Doktora Pisma Swiętego Deffinitora Prowinciey Ruskiey y Litewskiey Regenta y Kaznodzieię Konwentu Wilenskiego Panny Maryiey na Piasku Zakonu Franciszkanskiego Dnia 20 Marca Roku 1652, Wilno 1652, k. [C $\left.\mathrm{C}_{4}\right]-\mathrm{k}$. Dv.

${ }^{10}$ [Bartłomiej Wieczorkowski], Kazanie Na Pogrzebie [...] Pani Anny Grabianki z Wierbna Ciswicki Kasztelanki Srzemski, Pani Wielką pobożnością y mądrością sławney. Przez Wielebnego [...] Plebana Rydzynskiego. W Rydzynie w Kościele Swiętego Stanisława farskim IV. Decembris, Anno Salutis M.DC.XXVIII. odprawione. Z Dozwoleniem Starszych. Poznań 1629, k. $\mathrm{C}_{2}$.

11 Por. E. E. Wróbel, Chrześcijańska rodzina w Polsce. Między ideałem a rzeczywistościa, Kraków 2002, s. $164 ; 166$. Na temat wychowania i wykształcenia dzieci w dawnej Polsce zob. K. Bartnicka, I. Szybiak, Reformy oświatowe na ziemiach polskich w XVI-XX wieku, „Kwartalnik Pedagogiczny”, 1995, nr 3, s. 3-9; S. Litak, Z problemów edukacji dziewczat $w$ Polsce $w$ XVII-XVIII wieku, ibidem, s. 29-53; idem, Francuski nurt $w$ wychowaniu i szkolnictwie w Polsce $w$ XVII i XVIII wieku, w: Ecclesia Posnaniensis. Opuscula Mariano Banaszak Septuagenario Dedicata, pod red. F. Lenorta, K. Lutyńskiego, Poznań 1998, s. 139-148; B. Popiołek, ,Za małego wieku nauczyłam się...” - różne drogi kształcenia kobiet w epoce saskiej, „Biuletyn Historii Wychowania" 1998, nr 1-2, s. 5-10; E. E. Wróbel, Dyskusja nad modelem wychowania religijno-moralnego w rodzinie chrześcijańskiej w XVII wieku, „Nasza Przeszłość” R. 91:1999, s. 153-169; U. Augustyniak, Sytuacja kobiet na dworach ewangelickiej szlachty i magnaterii w XVII wieku, w: Między barokiem a oświeceniem. Obyczaje czasów saskich, pod red. K. Stasiewicz, S. Achremczyka, Olsztyn 2000, s. 125-131; D. ŻołądźStrzelczyk, Miasto a możliwości edukacyjne córek mieszczańskich w epoce przedrozbiorowej, w: XVI Powszechny Zjazd Historyków Polskich. Przełomy w historii, Wrocław 15-18 września 1999. Pamiętniki, T. III, Część 4, pod red. K. Ruchniewicza, J. Tyszkiewicza, W. Wrzesińskiego, Toruń 2001, s. 277-286; Studia z dzie- 
dziewcząt, na temat których wypowiadano się rzadziej i mniej szczegółowo. Edukacja szlacheckiej czy mieszczańskiej córki miała odbywać się w domu rodzinnym. W takim tonie wypowiadali się Andrzej Frycz Modrzewski (1503-1572), Mikołaj Rej (1505-1569) i Piotr Skarga (1536-1612), a więc przedstawiciele różnych środowisk społecznych i zwolennicy nietożsamych poglądów. Dorota Żołądź-Strzelczyk pisze, że w polskiej literaturze pedagogicznej wyróżnić można dwa typy wychowania kobiet. Pierwszy z nich „konserwatywny” - sięgał korzeniami do starożytności i ograniczał się tylko do wychowania religijno-moralnego, które przygotowywało dziewczynę do przyszłej roli żony, matki i gospodyni. Drugi zaś ,postępowy” - dostrzegał w kobiecie istotę równą mężczyźnie, stąd obok przystosowania do życia w rodzinie, kobieta mogła się rozwijać intelektualnie ${ }^{12}$. Jednak bez względu na to, jaki model wybrano, starano się przygotować pannę do roli dobrej żony i matki, gdyż „niewiasta mądra [jest - U. K.] na ozdobę domu swego"'13, co podkreślił ksiądz Wawrzyniec Janowicz podczas pogrzebu Heleny Szemiotówny Stachowskiej (zm. przed 15 III 1668), skarbnikowej wiłkomirskiej.

Jak zatem należało kształcić i wychowywać dziewczęta? Córki magnatów i bogatej szlachty zdobywały podstawy wiedzy na dworach magnackich lub w szkołach klasztornych, uboższym zaś musiało wystarczyć kształcenie domowe. Jednak bez względu na stan społeczny i majątkowy wpajano dziewczętom przede wszystkim zasady dobrego wychowania i starano się je ustrzec przed gorszącym wpływem otoczenia ${ }^{14}$.

W domu rodzinnym, jak już wspomniano, pierwszym wychowawcą dla swoich dzieci była matka, rzadziej ojciec, czasem prywatny nauczyciel. Do kobiet należała nie tylko pielęgnacja dzieci, ale także kształtowanie ich charakteru i umysłu. Stąd zwracano uwagę na osobowość matki, szczególnie na jej skłonność do kłótni i waśni, ponieważ złości, która się [...] pokazuje $w$ dziateczkach nie tak winien ojciec, jako matka ${ }^{15}$ - podkreślał dominikanin Hiacynt Mijałkowski w kazaniu ku czci Anny z Ruśca Lubomirskiej (zm.

jów edukacji...; M. Serwański, Na marginesie badań nad edukacja szlachcianek w Polsce XVI-XVII wieku, w: Cala historia to dzieje ludzi... Studia z historii spolecznej ofiarowane profesorowi Andrzejowi Wyczańskiemu $w$ 80-ta rocznicę urodzin i 55-lecie pracy naukowej, pod red. C. Kukli, przy współudziale P. Guzowskiego, Białystok 2004, s. 149-155.

12 Por. D. Żołądź-Strzelczyk, Dzieje edukacji kobiet..., s. 36.

${ }^{13}$ [Wawrzyniec Janowicz], Reszta Pociech W Umbrach Y Ciemiach Smiertelności Na Pogrzebie [...] Paniey Heleny Szemiotowny Stachowskiey Skarbnikowey Wilkomirskiey iako Małżonki, tudziesz y Matki [...] Paniej Helzbiety Toloczkowny Stachowskiey Kazaniem Upatrzona. Przez Wielebnego [...] Kanonika Wendenskiego, Prothonotariusza Apostolskiego, Dziekana Kupiskiego, Plebana Swiadoskiego, w Kosciele Onikscienskim Roku 1668. Marca 15. Wilno 1669, k. [D $]$.

${ }^{14}$ Por. E. E. Wróbel, Chrześcijańska rodzina $w$ Polsce..., s. 188. Zob. też W. Urban, Nauczanie domowe a szkolne w Małopolsce od XVI do XX wieku, w: Wychowanie w rodzinie od starożytności po wiek XX. Materiały z konferencji naukowej Katedry Historii Wychowania - czerwiec 1993, pod red. J. Jundziłła, Bydgoszcz 1994, s. 203-204.

${ }^{15}$ [Hiacynt (Jacek) Mijakowski], Znaczna W Cnotę Matrona [...] P. Anna z Rusce Lubomirska, Hrabina na Wiśniczu, Kasztellanka Woynicka, Sędomirska, Spiska, Dobczycka, etc. Starościna. Dnia 3. Lutego, W Krakowie u świętey Troyce, schowana; A przy Pogrzebie, Od [...] Dominikanina, Theologa, Przeora tamże u ś. Troyce, y Kaznodzieie u Fary, z Kathedry pochwalona. Teraz zaś Z cnotami swemi na pamiątkę potomnym wiekom a na pociechę pozostałey Familiey Drukiem wystawiona. Z dozwoleniem Przełożonych. Roku Pańskiego M. DC. XXXIX. Kraków 1639, s. 22. 
przed 3 II 1639), pani na Wiśniczu. Na początkowym etapie rozwoju pod opieką matki znajdowały się nie tylko córki, ale także synowie. Stąd można wnioskować, że w przestrzeni domowej, pomimo patriarchalnego układu stosunków, wpływ matki na swe dzieci był ogromny. Ona bowiem pokazywała i wyjaśniała im tajemnice życia, formułowała zakazy i nakazy oraz wprowadzała je w świat norm i zasad, które rządziły nowożytnym społeczeństwem ${ }^{16}$. Do niej należało także stworzenie odpowiedniej atmosfery rodzinnej. Stąd kobieta uznana została za serce i niejako ognisko duchowe domu rodzinnego. Jako matka nie tylko dawała życie swoim dzieciom, karmiła je swoją piersią, uczyła wiary i nauki, ale wykorzystując swoje cechy i przywileje, czyniła wygodne ,gniazdo” dla swej rodziny. Wpływ kobiety na ognisko domowe, w odróżnieniu od mężczyzny był ciągły i podtrzymywany uczuciem, które kształtowało i cementowało jej stosunki z dziećmi ${ }^{17}$. Bezpośrednia opieka matki nad dzieckiem w okresie baroku miała miejsce do siódmego roku życia, a w przypadku dziewczynek jeszcze dłużej. Za wzorową matkę uchodziła Zofia z Wielkiej Wsi Giżycka (zm. 1674), sędzina wieluńska, która zdaniem paulina Tobiasza Czechowicza swoje dzieci nauczyła pobożności, cnót świętych, dawała [im też - U.K.] wychowanie przystojne, szlacheckie"18. Rozsądną matką była także Zofia z Druckich-Lubeckich Laskowska (zm. przed 23 I 1649), żona Pawła, która ważyła sobie dziatki, które P[an] Bóg albo ma dać, albo dat [...], ważyła oko swoje jako pogladać, ważyła ucho, czego słuchać, ważyła język jako mówić, ważyła śmiech komu się $i$ czemu uśmiechać, ważyła jedzenie [...] jako miernie jeść [i - U.K.] trzeźwo pić [...] $]^{19}$. Dość nietypowe i radykalne podejście do wychowania swoich dzieci miała natomiast Zofia z Mikołajewskich Zalewska (zm. przed 4 II 1647), pisarzowa ziemska sieradzka, która wolała patrzeć na dziatki umarte, niżeli na grzeszqce. Milszy jej [był - U.K.] trup bez grzechu, niż żywy czlowiek bez Boga ${ }^{20}$.

Zatem, jak można wnioskować, kobiety kształtowały osobowość swoich dzieci, a w szczególny sposób wpływały na charakter swoich córek, gdyż w nich właśnie pozostawał żywy Konterfekt Macierzyńskiej zacności, godności, ludzkości, łaskawości, wspa-

16 Por. M. Bogucka, Staropolskie obyczaje w XVI-XVII wieku, Warszawa 1994, s. 67.

17 Por. Encyklopedia wychowawcza, pod red. J. T. Lubomirskiego, Warszawa 1881, s. 283-292, cyt. za B. Parysiewicz, Z badań nad rozwojem polskiej myśli pedagogicznej o wychowaniu w rodzinie, w: Wychowanie $w$ rodzinie od starożytności po wiek XX. Materiały z konferencji naukowej Katedry Historii Wychowania czerwiec 1993, pod red. J. Jundziłła, Bydgoszcz 1994, s. 215.

${ }_{18}$ [Tobiasz Czechowicz], Pole Buyney Pasze, Dziedzicznego Prawa Dekretem Na Opas Herbowemu Pułkozycowi Oddane A Przy Załobnym Akcie Wielm: [...] Pani Zophii z Wielkiey Wsi Gizyckiey Sędziny Wielunskiey, Cnot Pobożności y Wysokiego Urodzenia Nałęczą Opasane. Y Kazaniem Przy Przezacnego Zgromadzenia Audientij w Kościele Łyskorńskim. Ogłoszone Przez [...] Zakonu S. Pawła Pierwszego Pustelnika Prowincij Polskiey Definitora y Kaznodzieie Iasney Gory Częstochowskiey. Za dozwoleniem Starszych. Kraków 1674, k. [B $\left.{ }_{4}\right]$ v.

${ }^{19}$ [Michał Ginkiewicz], Kazanie Na Pogrzebie Dobrey Pamięci [...] P. Zofiey z Drucka Lubeckiey. Pawłowey Laskowskiey Przez [...] Proboszcza Domu Professow Wilenskiego y S. Theologiey Doktora, Societatis Iesu miane. A za dozwoleniem Starszych w druk podane. Wilno 1649, k. [C $\left.{ }_{4}\right]$ v.-k.D.

${ }^{20}$ [Paweł Kaczyński], Strzała Zacnego Domu [...] Panow Mikołaiewskich, Abo Kazanie na Pogrzebie [...] P. Zofiey z Drzewiec Zaleskiey, Pisarzowey Ziemskiey Sieradzkiey. Miane w Piotrkowie Przed Prześwietnym Trybunałem Koronnym, W Kościele Wielebnych Oycow Zakonu S. Franciszka De Observantia Przez [...]. 4. Dnia Lutego, Roku 1647. W Poznaniu w Drukarni Wojciecha Regulusa, 1647, k. D2v. 
niałości, miłości ku Panu Bogu, i ku Wielmożnemu Małżonkowi swemu [... $]^{21}$. Warto też dodać, że opieka matki nad dzieckiem, pomimo osiagnięcia przez nie odpowiedniego wieku - trwała właściwie bezustannie. Tak bowiem postępowała Elżbieta Myszkowska (zm. przed 11 I 1644), marszałkowa koronna, która swego syna wychowawszy [...] zdrowo $w$ dzieciństwie, wyćwiczywszy pobożnie $w$ młodości, na starość swoimi codziennymi [...] paciorkami i ustawicznym nabożeństwem ratowała $w$ niebie $e^{22}$.

Głównym celem kształcenia domowego było zdobycie praktycznej wiedzy na temat obyczajów i prac domowych. Czasem dochodziła do tego nauka czytania i pisania. Starano się także pracować nad charakterem młodej panny, za co odpowiedzialni byli zarówno rodzice, jak i Kościół. Zgodnie z powyższym schematem wychowywała swoje dzieci Katarzyna Szczawińska (zm. 1661), starościna łęczycka. Wspomniał o tym Franciszek Wierusz Kowalski w słowach - dał jej Bóg zacne Potomstwo, umiała mu Chrześcijańskq dawać edukację, nie tak swobodnie i pieszczenie wedtug ciała chowajac, jako pobożne i świqtobliwe względem ducha w bojaźni Bożej ćwiczqc ${ }^{23}$.

Pannę należało także ćwiczyć w pokorze, pobożności, wstydzie i cichości, ponieważ panieństwo serdeczne jest, zupetna wiara, gruntowna nadzieja, szczera miłość ${ }^{24}$. W kontaktach z mężczyznami radzono jej, by zachowała milczenie i wystrzegała się wszelkiej poufałości. Dziewczyna powinna unikać wychodzenia z domu, polubić samotność, a wolny czas zająć głośną modlitwą i pobożnym rozmyślaniem. Zalecenia te odnajdujemy w kazaniu poświęconym Helenie Sapieżance Kuncewiczowej (zm. przed 23 II 1645), chorążynie lidzkiej, w którym kaznodzieja Aleksander Dubowicz zaznaczył, że panna ma siedzieć w domu jako gołębica nad wodami: nie latać, nie biegać, nie przejeżdzać się, gdyż licencję wchodzić z domu, przejeżdżać się - mężczyźnie tylko prawem obwarowat $P$ [an] Bóg25. W mowie ku czci Joanny Ludwiki z Tęczyna Gniewoszowej (zm. 1666), starościny radomskiej przeczytać możemy zaś, że kiedy się Panienka ruszy albo na odpust, albo na mięsopust, albo na jaka kędy publikę, to się powinna ze wszystkim domem wozić - z Panem Ojcem, z Pania Matka, nie sama [zaś - U.K.] z Panem młodym, jako to

${ }^{21}$ [Marcelin Doroszewski], Powazna Senatorka W Trzech Bramach przy Pogrzebie [...] Paniey Zophiey Zienowiczowny Słusczyney Woiewodziney Nowogrodzkiey Homelskiey etc. etc. etc. Starościney Wperspektywie Załobney Na Kazaniu Przez [...], Theologa, Kaznodzieię Wileńskiego, y Starszego Klasztoru Ostrowieckiego, Dominikanina. Prezentowana w Roku 1642 Dnia 14 Stycznia. Za pozwoleniem Starszych. Wilno 1642, s. $280-281$.

22 [Hiacynt (Jacek) Mijakowski], Zbozny Pobyt, Po śmierci..., s. 2.

${ }^{23}$ [Franciszek Wierusz Kowalski], Woz Ozdobny. Chwałą Polityczną y Duchowną okryty [...] P. Katarzynie Hrabiance na Skrzynnie Szczawińskiey, Łenczyckiey, Gąmbinskiey etc. Starościney. Na odprowadzenie z Krainy Smierci do niebieskich szczęśliwości, Przez [...] Zakonu S. Franciszka Oycow Reformatow Wielgopolskich Kaznodzieię; Thumskiego Poznańskiego. Nazaiutrz po Intodukciey tych że Oycow Reformatow w Kościele Szczawińskim Kazaniem pogrzebnym wystawiony. Roku Pańskiego 1661. Dnia 21. Listopada. Poznań1661, s. 790. k. $\mathrm{B}_{2}$

${ }^{24}$ [Bartłomiej Wieczorkowski], Kazanie Na Pogrzebie [...] Pani Anny Grabianki z Wierbna Ciswicki...,

25 [Aleksander Dubowicz], Haft Ręką Bozą Nadobrey duszy [...] Paniey Heleny Sapiezanki Kuncewiczowey, Chorążyney Lidzkiey Koniawskiey Dubieckiey etc. Starościney, Położony. A Przez [...] Archimandrytę Wileńskiego Przy pogrzebie Załosnym Roku 1645. Mśca Lutego Dnia 23. W Cerkwi S. Troyce Oycow Bazilianow w Wilnie Kazaniem obiaśniony. Wilno 1645, k. D 2 v. 
cudzoziemskie wprowadzaja obyczaje, gdzie wiele młodym pozwalaja [... $]^{26}$. Zgodnie z powyższymi zaleceniami wychowywano Barbarę z Pilce Przyłęcką (zm. przed 17 II 1650), kasztelankę oświęcimską, która nie chodziła w nocy z gtupimi Pannami [...] ale z madrymi w domu zostawała [...] dobrze wiedzac, że $w$ domu saluty Anielskie ${ }^{27}$. Podobnie czyniła księżna Anna ze Sztemberku Ostrogska (zm. 1635), która pilności wielkiej przykładała, aby $w$ tym panieńskim stanie, w pańskich obyczajach, jako najbardziej się ćwiczyla ${ }^{28}$.

Ważnym elementem panieństwa, ustawicznie wpajanym przez dobrą matkę, była także skromność i stateczność, gdyż nie złoto, nie uroda, ani bogate na mode francuska wykrojone szaty, ale skromność w obyczajach zdobia i zalecaja płeć białogłowskq ${ }^{29}$. Cechy te posiadała Anna Maria z Zięblic Oraczowska (zm. 1664), dlatego kaznodzieja Franciszek Kochanowski, w kazaniu wygłoszonym na jej pogrzebie zaznaczył, że w wesołej cerze i poważnym biegu Przezacna heroina nasza wiek Panieński odprawita. Nie o krasionych włosach, [...] myślała, ale Chrystusowi nabożnie służyła; nie wonnemi kwiatkami ciało śmiertelne pstrzyła, ale przystojnymi obyczajami duszę nieśmiertelna stroiła $^{30}$. Zdaniem kaznodziei Mateusza Lisickiego Barbarę i Jadwigę Szołdrskie, córki Jana, cześnika kaliskiego, zdobiły nie powierzchowne kolory, nie utratna ciekawość, nie w każdy kat wejrzenie, nie podejrzana polityka, ale rumiany wstyd, skapa mowa, od rozmówek stronienie, w cnotach panieńskich i pobożności ćwiczenia. Dni nie schodziły im na próżnowaniu, ale na poczciwych zabawkach szlacheckich, na ćwiczeniu w doskonatościach panieńskich. Nie przeszkodziły tym pobożnym pannom żadne niepogody, nic deszcze, nic niesposobność drogi do Kościoła, na każdy dzień Mszy Świętej stuchać. Z kościota przyszedtszy zaraz do krosienek każda do swojej sobie osobnie skrzyneczki szła ${ }^{31}$. Również o Magdalenie z Zakliczyna Stradomskiej (zm. 1670), reformata Franciszek Rychłowski powiedział, że w oczach prawi tej Panienki nie było nic zdrożnego, w słowach tej Panienki nie było nic bezpiecznego, w uczynku tej Panienki nie było nic niewstydliwe-

${ }^{26}$ [Woyciech Tymonowski], Topor Z prochu Pogrzebowego Przepolerowany y na kark Smierci Przy Anniwersarzu [...] P. Ioanny Ludowiki z Tęczyna Gniewoszowey Staroscicowey Radomskiey Przez [...] Plebana Blotnickiego Wyostrzony y przyhartowany W kosciele Polickiem Dnia 16. Września Roku Pańskiego 1666. Kraków 1666, s. 11.

${ }^{27}$ [Jan Chryzostom Bodzenta], Białogłowa Męzna W rzadkowidaney Bogoboyności [...] P. Barbary z Pilce Przyłęckiey, Kasztellanki Oświęcimskiey, etc. Przy żałobnym ciała iey zmarłego Pogrzebie w Kościele Krakowskim franciszkańskim, Przez [...], Kaznodzieię Zamkowego, dnia 17. Lutego w Rok Iubileuszowy 1650. Znaleziona. A potym Praelo publico za dozwoleniem Urzędu Duchownego Kraków 1650, s. $284-285$.

${ }^{28}$ [Marcin Hincza], Złota Korona Abo Kazanie Na Pogrzebie [...] Xiężny Anny z Sztemberku Ostrogskiey, Hrabiney na Tarnowie, Woiewodziney Wołyńskiey. Ktore miał [...] Prowincyał Polski Societas ISEU. Dnia 7 Stycznia. Roku 1636 W Kościele Iarosławskim Societatis Iesu. Za dozwoleniem Starszych, y Urzędu Duchownego. Kraków 1636, k. Cv.

${ }^{29}$ [Wojciech Józef Korpalewski], Obraz w Podobienstwach, Prawowierney chrześcianskiey Pani Albo Kazanie na Pogrzebowym Akcie [...] Pani Magdaleny z von Holtow Czapskiey, Starościny Parchowskiey Miane dnia siodmego Lipca w Kościele Komorskim Od [...] Roku M.DC.LXXVIII. Cum licentia Superiorum. Gdańsk 1679, k. [Ciiij]v.

${ }^{30}$ [Franciszek Kochanowski], Korona Sowita Z Honoru..., s. 394.

${ }^{31}$ [Mateusz Lisicki], Lodz Do Szczęsliwego Portu..., k. F $\mathrm{F}_{2}$; k. $\mathrm{F}_{3}-$ k. $\mathrm{F}_{3} \mathrm{v}$. 
go, w obyczajach tej Panienki nie było nic miękkiego, w chodzie tej Panienki nie było nic rozpustnego, w głosie tej Panienki nie było nic swawolnego ${ }^{32}$.

Zdaniem Macieja Serwańskiego wykształcenie intelektualne szlachcianki w okresie staropolskim było zbędne, gdyż należało przystosować ją do zadań gospodarskich. Stąd podczas domowej edukacji uczono ją szycia, robienia pończoch, haftowania, zdobienia szat liturgicznych, czy też wyściełania bawełną kaftanów pod pancerze lub kolcze zbroje. Dziewczęta miały także nabierać odpowiednich manier, uczyć się tańca lub gry na instrumentach $^{33}$. Takie wychowanie zdaniem kaznodziei Pawła Kaczyńskiego otrzymała Zofia z Mikołajewskich Zalewska (zm. przed 4 II 1647), pisarzowa ziemska sieradzka, która w młodości została wysłana na naukę do swej rodzonej ciotki Bogumiły Zamoyskiej byty tam pewne godziny na ręczna robote, na modlitwę $i$ na insze prawie klasztorne zabawy $y^{34}$.

Na podstawie powyższych rozważań wnioskować należy, że odebranie odpowiedniego domowego wychowania kształtowało kobietę na całe dorosłe życie, jak również miało wpływ na jej osobowość oraz stosunek do swego męża i dzieci. O Zofii Zienowiczównej Słuszczynie, kaznodzieja Marcelin Doroszewski powiedział, że wywodziła się ze szlachetnej senatorskiej rodziny, w której miała „rozkochane dzieciństwo” i otrzymała przykładne wychowanie ${ }^{35}$. Dobre wychowanie w domu rodzinnym odebrała także Helena Sapieżanka Kuncewiczowa (zm. przed 23 II 1645), chorążyna lidzka. Kaznodzieja Aleksander Dubowicz, głosząc kazanie na jej pogrzebie zaznaczył, że właściwie przez całe życie pamiętano, jakie [...] ta gołębica w Jaśnie Wiel[możnym] Domu Sapieżynskim ćwiczenie miała jako podrastała i piórami ślicznych cnót się przyodziewała jako w młodym wieku wielu cnotami i darami Bożemi przewyższała. Do tego pamiętano, jako taż gotębica z gniazda rodzicielskiego przeniesiona $i$ w stan matżeński oddana byta ${ }^{36}$.

Wypadki losowe sprawiały, że czasem bohaterkę oracji nie wychowywała matka, ale opiekę nad nią przejmowało rodzeństwo lub najbliższa rodzina. Częstą praktyką było także wysyłanie młodej panny na naukę do szkoły przyklasztornej. Na temat wychowania księżnej Anny ze Sztemberku Ostrogskiej, jezuita Marcin Hincza powiedział, że choć wcześnie została sierotą, a opiekę nad nią przejął brat, to jednak dobroć i szczodrość, którymi się odznaczała, musiała wyssać z mlekiem matki, ponieważ tak dobra Matka, tak dobrq Córke zrodziła. Wspomniany brat natomiast wykształcił ją w takiej poważności, że $i$ w klasztorze lepszego by wychowania [...] nie miała ${ }^{37}$. W obcym domu wycho-

32 [Franciszek Rychłowski/Rychłowiusz], Stroy Białogłowski A oraz y Męski, Panu Bogu, y Ludziom wielce przyiemny, Którego Zyiąca na świecie używała, (nadzieia w Bogu że y w niebie używa) Przezacnie Urodzona [...] P. Magdalena z Zakliczyna Stradomska, W Kazaniu przy Akcie pogrzebowym, w Kościele Sczucinskim Przez [...] Reformata, w Krakowie u Swiętego Kazimierza Kaznodzieie Pokazany Dnia Ośminastego Sierpnia Roku Pańskiego 1670. Kraków 1670, k. [B $\left.\mathrm{B}_{4}\right]$ v. s. 151 .

${ }^{33}$ Por. E. E. Wróbel, Chrześcijańska rodzina w Polsce ..., s. 189; M. Serwański, Na marginesie badań...,

34 [Paweł Kaczyński], Strzała Zacnego Domu..., k. B 2 v.

35 [Marcelin Doroszewski], Powazna Senatorka W Trzech Bramach..., s. 291.

36 Aleksander Dubowicz], Haft Ręką Bozą Nadobrey..., k. Dv., k. [F. ]v.-k.G.

${ }^{37}$ [Marcin Hincza], Złota Korona Abo Kazanie..., k. C-k.Cv. 
wana została także Konstancja Hilaria Wołłowiczówna Grabińska (zm. przed 23 III 1678), chorążyna brzesko-litewska. Dowiadujemy się o tym z oracji wygłoszonej przez dominikanina Michała Wojniłowicza. Kaznodzieja wspomina w niej, że matka nieboszczki umarła młodo, przez co Konstancja trafiła pod opiekę Zuzanny Gosiewskiej Wilczkowej, kasztelanowej trockiej. Grabińska otrzymała tam dobre wychowanie wyssysajac z obyczajów i dzieł pobożnych tej świętej Paniej wszelka słodycz zbawienna i wzór pięknych po tym progresów $w$ dalszym pożyciu ${ }^{38}$. Ciekawym przykładem jest także Konstancja z Lubomirza Czarnkowska (zm. 1646), starościna międzyrzecka i pyzdrska, która w młodości wcześnie straciwszy matkę oddana została na wychowanie swoim babkom. Najpierw znajdowała się pod opieką wspomnianej księżnej Anny ze Sztemberku Ostrogskiej, a po jej śmierci przekazano ją na dwór opisanej już Anny z Ruśca Lubomirskiej, gdzie nic [...] nie było tylko Bojaźń Boża, skromność, poczciwość, a nade wszystko nabożeństwo $i$ wstyd panieński. [...] [gdyż - U.K.] białogłowa niezamężna o tym tylko myśli, jakoby się Bogu podobać $i$ wolniej ku niebu sercem wylatywać [...] $]^{39}$.

Wychowanie klasztorne otrzymały natomiast Ewa Anna Pszonczyna (zm. 1643), chorążyna chełmska, oraz Konstancja Krystyna Wielopolska (zm. 1675), stolnikowa koronna. Dominikanin Hieronim Makowski, głosząc kazanie na pogrzebie chorążyny, wspomniał, że jej „ćwiczenie z młodu” dotyczyło poszerzania wiary, pobożności i bogobojności. Stolnikowa koronna zaś po śmierci swych rodziców trafiła do warszawskiego klasztoru „Świątobliwych Panien Zakonu S. Franciszka de Sales” (tj. wizytek). Tam też otrzymała gruntowne, religijne wychowanie, którym kierowała się przez resztę swojego życia. Również swoje dzieci nie tak swobodnie i pieszczenie wedtug ciała chowała, jako pobożnie i światobliwie względem Ducha ćwiczyła. Stąd, ku zdziwieniu kaznodziei Ludwika Różyckiego, już trzyletnia córka Wielopolskiej znała podstawowe prawdy wiary, czym wprawiała w zakłopotanie niejednego dorosłego ${ }^{40}$. Marcjanna z Daniłowiczów Koniecpolska (zm. 1646), wojewodzina ruska zaś, będąc panną, chciała zostać zakonnica. Z jej decyzją nie zgodzili się jednak rodzice, stąd przez całe swe życie

${ }^{38}$ [Michał Wojniłowicz], Pszczołka z Ziemskiego Kwiecia, do Niebieskiego lecąca Ula, [...] Pani Konstancya Hilarya Wołłowiczowna Grabińska Woiewodztwa Brzeskiego Chorązyna w Berezie Roku 1678. Dnia 23. Marca Przy Pogrzebowey Pogodzie, Przez [...] S. Th. D. P. W. D. S. W. K. L. Z. K. D. S. Słowa Bożego kunsztem Osadzona. Wilno 1678, s. 12.

${ }^{39}$ [Wojciech Pigłowski], Rzeka Pokoiu y Strumien Powodz Sławy Niosący To iest: Kazanie na Pogrzebie [...] Paniey Konstancyey z Lubomirza Czarnkowskiey Miedzyrzeckiey, Pyzdrskiey, etc. Starosciney. Miane w Kościele Czarnkowskim, Przez [...] Kanonika Poznańskiego, Wałeckiego Proboszcza, I. Octobr:1646. Poznań 1646, k. C-k.Cv.

${ }^{40}$ [Hieronim Makowski], Trzy Splendori Zacności Bialogłowskiey. Pokazane na Pogrzebie, [...] P. Ewy Anny Pszoncyney. Choraziney Chelmskiey Przez [...] S. Pisma Doktora, Kaznodzieię Lubelskiego, Zakonu Kaznodzieyskiego. W Kościele Lubelskim, S. Stanislawa, Oycow Dominikanow. 9. April. Anno Dni. 1643. Lublin 1643, k. [D ]; [Ludwik Różycki], Rzeka Troista Korczakowska Przedtym po ziemskich dolinach, Teraz Po niebieskich płynąca pagórkach, Przy żałobnych Exequiach [...] P. Konstancyey Krystyny Wielopolskiey, Stolnikowey Koronney, Generałowey Małopolskiey, Krakowskiey, Nowotarskiey, Bocheńskiey etc. Starosciney. Z Ambony Bieckiey u Oycow Reformatow Roku Pańskiego 1675. Dnia 15. Marca Pokazana. Przez [...] Zakonu S. Franciszka tychże Oycow Reformatow, Prowinciey Małopolskiey Prowinciała, a przedtym S. Theologiey Professora. Kraków 1675, s. 8-9. 
zachowywała się tak, jakby ,żywot zakonny” prowadziła ${ }^{41}$. Takie samo pragnienie miały Marianna z Miaskowa Koźmińska (zm. 1685) i Anna Kandzierzawska Tyszkiewiczowa (zm. 1653), marszałkowa słonimska, która ciesząc się, że z Rodziców Katolickich urodzo$n a, w$ wierze Katolickiej wychowana [...] w stanie jeszcze Panieńskim będac Bogu się ślubem zakonnym oddać pragnęta $[\ldots]]^{\prime 42}$.

Podsumowując, należy stwierdzić, że dzieciństwo i panieństwo stanowiło ważny okres w życiu kobiety. Był to bowiem czas, kiedy pod wpływem najbliższej rodziny, a zwłaszcza matki - kształtowała się jej osobowość, wrażliwość i wiedza. W dawnej Polsce młode dziewczęta mogły się uczyć w domu rodzinnym lub w szkole przyklasztornej. Zdarzało się także, że panny oddawano na wychowanie na dwór magnacki lub królewski. Jednak bez względu na miejsce, w którym dziewczyna pobierała naukę, przygotowywano ją do zasadniczej roli życiowej, czyli żony i matki oraz ćwiczono w wierze, bojaźni Bożej, pokorze i wstydliwości, ponieważ póki niewiasta nie pójdzie za maż, ma mieć stróża lwa, bo pospolicie Ojciec i matka, bracia i opiekunowie, którzy [...] Pannę trzymaja, ci Pannę czysta $i$ bez makuly na ślubny kobierzec stawiaja ${ }^{43}$. Dziewczynie wpajano ponadto podstawowe zasady kultury osobistej oraz podkreślano umiar w kontaktach z mężczyznami. Wymagano od niej by była skromna, małomówna i cicha. Zwracano uwagę na to, by zachowała powściągliwość w ubiorze. Dopuszczalne były wprawdzie pewne ozdoby ze srebra lub złota, ale miały one świadczyć jedynie o statusie społecznym młodej szlachcianki i prestiżu rodziny, z której się wywodziła. Wykształcenie intelektualne nie było koniecznościa, gdyż za ważniejsze uchodziło to, by przygotować dziewczynę do zajęć gospodarskich, prowadzenia domu i zajmowania się dziećmi.

${ }^{41}$ [Jędrzej (Andrzej) Cyrus], Kazanie Na Pogrzebie [...] P. Martiany Daniłowicowney Koniecpolskiey, w Kościele Przecławskim, [...] Karmelitę Bossego, Kathedralnego Kościoła Krakowskiego Kaznodzieie Ordinariusza . Przez X. Iana Grzybowskiego, Proboszcza Przecławskiego do druku podane. Z dozwoleniem Starszych. Kraków 1646, k. B 3 , s. 9.

42 [Jan Janiszowski], Kazanie Na Pogrzebie [...] P. Maryanny z Miaskowa Kozminskiey Znaczney Dobrodzieyki Collegium Kaliskiego Soc: Iesu Miane W Kościele tegoż Collegium Przez [...] Societatis Jesu. Roku 1685. W Drukarni Collegium Kaliskiego Societatis Jesu. Kalisz 1685, k. B2v.; [Rajmund Zajączkowski], Morze Od brzegu śmiertelności do Portu odpocznienia [...] Panią Annę Kandzierzawską Tyszkiewicową Marszałkową Słonimską prowadzące. Z łez Wielmożnego Jego Mości Pana Piotra Tyszkiewica Marszałka Słonimskiego Małżonka wspławione. Wzdychaniem prześwietnego potomstwa wzburzone. Pogrążeniem pociech domostwa zacnego srogie Ktoremu [...] S. Th: L. Dominikanin brzegi y granice uczynił y na Kazaniu pogrzebowym w Zurowicach mianym szerokość przemierzywszy nawałność uśmierzył. Roku 1653. Dnia 30. Octobra. Wilno $1653, \mathrm{k} .\left[\mathrm{C}_{4}\right]$.

${ }^{43}$ [Michał Ginkiewicz], Kazanie Na Pogrzebie Dobrey Pamięci..., k. $\left[\mathrm{C}_{4}\right] \mathrm{v}$. Na ten temat zob. także [Aleksander Lorencowic], Kazania Pogrzebne miane w roznych załobnych okazyach Przez [...] Prowinciała Polskiego Societatis Iesu. W Koleium Kaliskim Societatis Iesu. Drukowane. Roku Pańskiego 1670, s. 193-194; [Wojciech Tymonowski], Topor Z prochu Pogrzebowego..., s. 11. 
